\title{
Cultural and Social Values of Science*
}

\section{SiR Richard Gregory, BT., F.R.S.}

$I^{\mathrm{T}}$ is difficult to define 'cultural value'; for there are many different standards by which it is measured. The term is often used to signify acquaintance with classical languages and literature, but a better view is that learning, whether classical or not, is comprised of many parts and that culture is the one indivisible whole made up of them. When science is taught, not as an aid to a vocation, but as part of the training of a modern citizen, it may justly be claimed to have a cultural value. The purpose of scientific study is to discover the truth about all things, including man, his instincts and impulses, his organization in society. The habit of mind developed by this disinterested pursuit may be as effective an ethical agency as that usually associated only with studies of what are called the humanities.

Cultural and social values are, however, rarely implied in the study of science, but with that of literature, history and other subjects believed to be of a more humane type. Even among scientific workers themselves, there are many who are content to regard experimental and observational inquiries as belonging particularly to the natural sciences, and are indifferent to the application of scientific methods to the investigation of social problems or the influence of scientific knowledge upon human thought. Recognition of interrelationships between all departments of learning is, however, becoming more common than it was a generation or so ago : and the forces which were formerly engaged in conflicts between science and religion or science and classics now profess joint interest in the cultivation of all fields of human enlightenment.

Science and literature, or what are called the humanities, are not now regarded by responsible authorities as opposing elements in education. The two terms should be considered as synonymous; for science rightly conceived is modern humanism in the fullest sense. Even if the humanities are under. stood to mean letters, history and art, there should be no conflict between these studies and natural knowledge.

But though scientific workers know well enough how science touches art and music, how it may enter into literature and how it makes history, there is not like appreciation of science from representatives of those schools of thought and teaching. It cannot be said that the intellectual horizon of men of letters of our own times has been extended by advances in modern science. There is not much evidence in the works of leaders of literature of assimilation of the now knowledge, or even of sympathy with it. Occasionally one finds a reasonable attitude towards the age of science and invention in which we live, but more usually there is an absence of an outlook which will regard science not merely as a storehouse of facts to be used for material purposes, but as one of the great human endowments to be ranked with art and religion and the guide and expression of man's fearless quest for truth.

- From contributions, made in the order here printed, to a discussion in Section 1 (Educationa] Science) of the British Association at Blackpool on September 10.
The influence of science upon material progress and human comfort is understood much more commonly than that of its effect upon the human mind. It is difficult for people of these times to realize the liberation of life and intellect brought about by the works of Copernicus, Galileo, Vesalius and other pioneers of scientific learning. The very foundations of belief were shaken when it was shown that the abode of man was not the centre of the universe but only a minor member of a group of planets revolving around a sun which was itself only one of many thousands of suns in stellar space. When Newton had shown that his law of gravitation was sufficient to account not only for the movements of the planets but also for the paths of the comets, it was no longer reasonable to believe that they were sent as signs or warnings to the human race. Consider the tremendous revolution involved in this substitution of permanent natural law for the conception of a world in which all events were believed to be reflections of the moods of a benign or angry God.

The sense of justice which resulted from the knowledge of the existence and permanence of law in Nature profoundly influenced human thought, and resulted in social changes which had the greatest civilizing effects.

Just as Copernieus deposed the earth from the position it was supposed to occupy in the universe, so Darwin placed man in a new relationship to the rest of living creatures. Science is concerned with the progress of knowledge and the evolution of man not only in the past but also in the present and future. We need not believe that man has degenerated from a state of perfect knowledge to that of being "born in sin and shapen in iniquity", or that the recovery of his lost position must be looked for not in this world but in the next. The adoption of this depressing doctrine is opposed to evolution as a whole and sub. servient to all progress. Unlike the creatures of the field, man can make his own environment and so promote the development of any type he desires to survive. The social heritage to which he succeeds has an important influence upon his thoughts and conduct, but he himself can exalt or degrade it.

The advance of science in modern times has had supreme social value in the alleviation of human suffering and increase in the capacities and facilities for human happiness. As whatever subjects are defined as cultural or humanistic must be understood as being concerned with the welfare of man, the conquest of disease as the result of scientific research may rightly claim a high place among them.

Progress in physies and ehemistry has profoundly altered those social conditions which it is the pur pose of social science to study. The immense increase in the productive capacity of mankind is forcing society to consider the human consequences of the unlimited resources now at its disposal.

Scientific methods applied to the fields of politics human biology, sociology, economics and psychology will enable facts to be ascertained and assembled for consideration by minds free from passion and preju dice, but knowledge of history and insight into humar nature will be required to arrive at sound conclusions and construct practicable policies upon them. 
In recent years, leading representatives of science have warned the world of the disastrous consequences which must ensue unless the gap is lessened between scientific advance and moral or ethical development in both national and international spheres. Unless science repudiates the methods of cultivated barbarism involved in modern warfare, it must lose whatever right it now possesses to be a spiritual influence and acknowledge with despair that man's ethical evolution has already reached its culminating point. Such an end cannot, however, be contemplated, and it will be avoided by conserving social and spiritual values with scientific teaching and research. With this unity of intention it will be possible to hope for and expect scientific guidance of human growth not only towards individual fitness but also towards a higher human perfection.

\section{Prof. Lancelot Hogben, F.R.S.}

We all know what is meant by the vocational aspect of education, and we wrongly assume that there is equally general agreement about the meaning of its cultural side. In theory, the word cultural commonly covers two entirely different functions of an educational system. One is the private problem of helping the individual to discover for himself or herself congenial sources of enjoyment to occupy leisure in after life with the fullest allowance for variety of temperament. The other is the public business of equipping individuals with the knowledge necessary for the discharge of their mutual responsibilities as co-citizens of a democratic society without regard to the personal inclinations of the child. In practice, what is called cultural education is neither the one nor the other. Good taste, which is synonymous with ostentatious refinement appropriate to a leisured class, takes precedence over the cultivation of individual satisfaction of temperamental needs, while political rationalizations of a bygone age exclude the study of resources for welfare which a modern community can use or abuse.

Increasing specialization and expanding outlets of vocational choice for individuals with a native inclination or aptitude for scientific studies must progressively limit the appeal of science as an active hobby. Meanwhile the demand of popular educational movements like the W.E.A. is for information about the social problems of our time. That science should be taught, because it teaches children to be observant and curious, is a dubious proposition. The case for science as an essential part of the education of the average man or woman does not rest on gratuitous assumptions about the transfer values of particular disciplines, or on the individual satisfaction which a small class of individuals may derive from verbal disquisitions on the latest, least digested discoveries at the periphery of theoretical research. The cultural claims of science rest on the social fact that the use and misuse of science intimately affects the everyday life of every citizen in a modern community.

While it is happily true that educationists are ahead of the scientific specialist in so far as the cultural teaching of science demands emphasis on its place in everyday life, the claims of science in the education of the citizen extend far beyond a passing familiarity with the way in which society at present uses the knowledge available for the advancement of human well-being. What is far more important is a recognition of the potential of human welfare in- herent in scientific knowledge, which existing social machinery fails to exploit for the common weal. Even this neglected aspect of the problem which confronts us in designing a general course of science to take its place in the curriculum of humanistic studies does not exhaust all the issues which should claim pre-eminence. Others emerge more clearly, if we consider the dangers with which the preservation of democracy is now faced. One is failure to anticipate the dire penalties we may pay for the misuse of science. Complacent acceptance of its prostitution to destructive ends, and ignorance of the constructive alternatives which existing knowledge places at our disposal, will have disastrous consequences for all of us, if the helplessness and horror of modern war is canalized in a revolt against science, a repudiation of the benefits which science can confer and a retreat to a lower level of civilized living.

In contradistinction to purely static emphasis on the place of science in everyday life to-day, education for citizenship demands a knowledge of how science is misused, how we fail to make the fullest use of science for our social well-being, and, in short, a vision of what human life could be, if we planned all our resources intelligently. It calls for understanding of the way in which social agencies foster new discoveries and their useful application. In addition, it must reinforce confidence in rational endeavour by emphasizing the role of advancing scientific knowledge in the growth of social institutions.

A course of general science adapted to the requirements of eitizenship should be orientated towards the elucidation of the major constructive achievements of natural knowledge in the evolution of civilization. Among the cardinal themes which thus replace the arbitrary division of science into separate 'ologies', those which claim special attention are the construction of the calendar, the technique of navigation and map making, the extension of deep-shaft mining and exhaustion of fuel supplies, the introduction of inanimate and mobile power, the discovery of chemical fertilizers and the principles of scientific breeding, the control of epidemic diseases and the national dietetic minimum. School science should not be a selection from the competing claims of specialist disciplines. It should be the story of man's conquest of time reckoning and space measurement, of the search for materials and substitutes, the liberation of natural sources of power and the struggle against hunger and disease. When it becomes this, the theoretical principles which have the greatest yield will emerge far more clearly, and there will be less reason for disagreeing about the relative importance of different aspects of scientific knowledge.

The indifference of men of science and educationists in the universities has relinquished one unique opportunity for implementing the cultural claims of science. It was offered shortly after the late European war, when the Civil Service Commission made a paper on Everyday Science compulsory for all candidates at examinations for higher grades. Provision of special instruction for such candidates, mainly drawn from the ranks of graduates who specialize in linguistic and historical disciplines, might have become a nucleus for the training of teachers for general science as a cultural subject. The examination proved to be a farce, presumably because no such provision was made until last year, when the Commissioners took the retrograde, if comprehensible, course of omitting Everyday Science 
from the list of compulsory papers. The only official recognition of the need for scientific knowledge in the administration of the nation's affairs was thus withdrawn. Such decisions are not necessarily irrevocable, and it is still possible to bring the pressure of public opinion to bear on the Civil Service Commission. If it can be persuaded to reconsider the matter, the British Association would perform a useful service by appointing a joint committee of educationists and men of science to draw up a syllabus of instruction, and urge the universities to provide it.

Whether science will take its needful place in the instruction of the citizen and statesman depends far less on the attitude of the scientific specialist than on that of the educationist. The scientific specialist is too much immersed in his work and too much imbued with an attitude of social indifference generated by a long period of comparative prosperity and security to take an active part in the educational reformation which the present crisis in democratic societies ealls for. The problems of the post-War world demand nothing short of a transvaluation of all educational values. Over-specialization is one of the great obstacles to their solution. If the educa. sionist is to make a constructive contribution to the social problems of the present time, he will have to forfeit the luxury of false modesty in his dealings with the claims of specialists.

\section{Sir A. D. HALL, K.C.B., F.R.S.}

The true aim of science is the enrichment of life. Through science man obtains an increasing control over the operations of Nature and the blind forces which limit his activities.

It is commonplace to enumerate the gifts of science to humanity during the last century, such as the speeding-up and extension of communications by steamboat, railway, motor-car and aeroplane. Science gives us new sources of light and heat in our households, unwonted textiles for our clothing, healthier and more attractive food. Science is minimizing the curse of Adam-manual toil. At one time a man required a week to dig an acre; the horse plough enabled him to do it in little more than a day, the modern tractor will make light of it in an hour.

Such gains may be dismissed as material only, but science has equally contributed to our spiritual enrichment. Consider only the enlargement of our knowledge of the world and of the appreciation of history that easy travel has brought, or the contacts with art that photography has made possible. The gramophone has brought the whole range of music within the reach of the ordinary man. Wireless is contributing to the mark of the educated manthat awareness of what is moving in the minds of men.

Yet only a few years ago in a sermon to the British Association, Bishop Burroughs appealed for a ten years' vacation for science. Science is beginning to take on the aspect of an enemy, frustrating the enjoyment of all the advantages it can offer. Science is regarded as dangerous because at the same time as it is conferring the powers of production, people at large are learning of these powers and beginning to ask why they cannot enjoy their fruits.

Seience means power, but it has given no consideration to whom that power should be entrusted and to what ends it should be used. The acceleratior of productive power has led to over-production anc unemployment; the sudden development of a ner invention may throw another town into long continued distress and poverty. The new develop ments of war methods by science are putting appalling powers of destruction into the hands 0 : Governments.

The greatest of all dangers lies in the temptatior that is now offered to the power-mongers. Once having obtained control of the machinery they car wipe out any further exercise of the popular will Of old, every autocracy ended in revolution; Wha. chance has a rising to-day against guns and gas Moreover, a subtler technique has been evolved, no: merely to control the people by force but also to subdu their minds until they will to be slaves. We are learnin! how the robot can be created by a Government con trolling the Press and all publications, closing the frontiers to all communications, using the wireles: and education as instruments of propaganda. Th old reformers fought for universal education; Dis they ever consider how it would be used to con solidate a tyranny? It is reported that the German are moving towards uniformity by the sterilization of the dissidents. The end is the ant community 0 soldiers and obedient workers.

Putting aside the fundamental question of whethe the fruits of science can be enjoyed by the whol community or only by the few, how far can th knowledge of science be shared? It is a commo: reproach that people are using science without under standing-they press a button or turn a switck This is no valid reproach; science is for th specialists, but general science should be the basis $c$ education for all, and in this lies the only hope fo the future. The specific value of education on basis of science is that it will encourage if not creat a habit of acting on reason rather than emotior One may recognize that emotion is the spring c action and yet realize that reason can exercise som control.

Party, Country, Religion-these are the kind c emotional issues which constitute the false mone wherewith the politicians buy power. They are a forms of the easiest of self-delusions-that of belon ing to $\&$ chosen race. Step by step the habit c illusion is built up-the old school tie, the club, th regiment, the social class, the nation. In themselve these loyalties are excellent, their dangerous side that they breed hatreds of the "lesser breeds withor the law". The function of an education based 0 science is to destroy this illusion and to teach peop] from their earliest formative years that men an women, however diverse as individuals, yet ari collectively and statistically, very much alike. maintain that this can be effected by a scientif education rather than a purely literary educatios The latter is concerned with the past, it pictur the world as governed by the play of emotion its effect is generally to induce a desire to repr duce the old world and to discourage any col fidence in the accelerated tempo science has broug] about.

But even education is not enough; men of scienı will have to organize to make their point of vie prevail. This is alien to the temperaments of tk leaders in the world of science. They want to remai in their laboratories and secrete knowledge withor bothering about its puxpose. To do so is to accer slavery. 